\title{
Long-term anaerobiosis in sublittoral marine invertebrates from the Western Baltic Sea: Halicryptus spinulosus (Priapulida), Astarte borealis and Arctica islandica (Bivalvia)
}

\author{
Rolf Oeschger* \\ Institut für Meereskunde an der Universität Kiel, Düsternbrooker Weg 20, D-2300 Kiel, Federal Republic of Germany
}

\begin{abstract}
Long-term anaerobiosis was studied in the priapulid Halicryptus spinulosus and the bivalves Astarte borealis and Arctica islandica, species with an extremely high resistance to lack of oxygen, from Kiel Bight. This shallow, brackish environment is frequently affected by extended periods of oxygen deficiency. Animals were experimentally subjected to anoxia for up to $60 \mathrm{~d}$. Glycogen was the most important substrate during long-term anaerobiosis, although it amounts to only 5 to $12 \%$ of soft tissue dry weight. Succinate, acetate and propionate were produced from glycogen degradation by anaerobic metabolic pathways. Succinate accumulation within tissues attained the highest concentrations found so far in marine invertebrates, and depended on duration of exposure to anoxia. Most $H$. spinulosus remained active during the first 3 or $4 \mathrm{wk}$ of anoxia. They contained only low levels of aspartic acid, which seems to be of minor importance as a substrate during long-term anaerobiosis. The activity of lactate dehydrogenase was low and lactate formation was also negligible. In $\mathrm{A}$. borealis, activities of lactate, alanopine, and strombine dehydrogenases were low under anoxia and only small amounts of alanopine and strombine were produced. Volatile fatty acids were produced by all 3 species; in $A$. borealis, acetate reached maximum concentrations during the transition phase from aerobic to anaerobic metabolism, whereas propionate was detected only after $2 \mathrm{~d}$ of anoxic incubation. Acetate and propionate concentrations remained low, the excess being excreted. A. islandica, on the other hand, produced propionate immediately at the onset of anoxic conditions, and accumulated high concentrations of acetate and propionate. Propionate excretion was nearly negligible. Calorimetric measurements on the bivalves showed that they reduced their metabolism by up to $40 \%$ during the first day of oxygen lack when they turned to anaerobic metabolism. After prolonged anoxia, energy release decreased to less than $1 \%$ of aerobic rates. These are the lowest rates found in marine invertebrates so far. A. islandica is able to undergo periods of self-induced anaerobiosis, and can reduce its glycogen consumption drastically, as can be calculated from calorimetric measurements. This behaviour may help it to withstand adverse environmental conditions.
\end{abstract}

\section{INTRODUCTION}

Short-term anaerobiosis, i.e. functional and environmentally induced anaerobic metabolism, has been studied extensively in marine invertebrates especially from intertidal areas (e.g. Zebe 1977, de Zwaan 1977, Schöttler 1979, Zebe et al. 1980, Gäde \& Grieshaber 1986, Fields \& Storey 1987, Schöttler \& Grieshaber

\footnotetext{
- Present address: Universität Bremen, Meereszoologie, Fachbereich 2, Außenstelle, Bürgermeister-Smidt-Str 20, D-2850 Bremerhaven, Federal Republic of Germany
}

1988, Storey 1988). However, little attention has until now been paid to long-term anaerobiosis, which may be maintained for several months by sublittoral marine invertebrates (Theede et al. 1969).

Hydrographic and anthropogenic influences may cause prolonged oxygen deficiency and high hydrogen sulfide concentrations in deeper parts of Kiel Bight (Ehrhardt \& Wenck 1984). Only few species, such as the priapulid worm Halicryptus spinulosus and the bivalves Astarte borealis and Arctica (Cyprina) islandica, are resistant enough to survive in these areas (Weigelt \& Rumohr 1986). 
Halicryptus spinulosus belongs to the phylum Priapulida, which comprises only a few species. It inhabits arctic-boreal waters, living in loosely structured burrows in the sediment down to $30 \mathrm{~cm}$ depth, and is able to withstand low oxygen contents, as well as hydrogen sulfide (van der Land 1970, Oeschger 1987). With increasing periods of oxygen deficiency in Kiel Bight in recent years, $H$. spinulosus has come into the center of interest, because its abundance has increased strongly in the muddy sediment below 18 to $20 \mathrm{~m}$ water depth, its preferred biotope. Its growing ecological importance in Kiel Bight and a lack of knowledge about its reaction to oxygen deficiency make this species an important subject for investigation.

Astarte borealis inhabits the soft sediments of Kiel Bight below $10 \mathrm{~m}$ of water depth and is characterized by low metabolic rates (Dries \& Theede 1974).

Arctica islandica is abundant in Kiel Bight. It is a major component of the food chain in this area (Arntz 1980). This species exhibits a peculiar behaviour of burrowing aperiodically into the sediment without obvious reason. It respires anaerobically when burrowed (Taylor 1976). A. islandica and A. borealis together amount for about $90 \%$ of the benthic biomass of Kiel Bight (Weigelt \& Rumohr 1986).

The species studied here have the highest $\mathrm{LT}_{50^{-}}$ values under oxygen deficiency known among marine invertebrates (Theede et al. 1969, Theede 1984, Oeschger \& Theede 1986). To maintain ATP production in the absence of oxygen, anoxia-resistant marine invertebrates use metabolic pathways different from the aerobic ones.

The aim of the present study was to find out which adaptations in these organisms are responsible for their long-term survival under anoxic conditions. For this purpose, changes in the concentrations of glycogen and several important metabolites characteristic of different anaerobic catabolic pathways, as well as the activity of enzymes involved in anaerobic glycolysis, were analyzed. In addition, calorimetric measurements were carried out. The data are evaluated in their ecological context.

\section{MATERIAL AND METHODS}

Collection and maintenance of animals. Halicryptus spinulosus von Siebold, 35 to $80 \mathrm{mg}$ dry wt, were collected with a triangular naturalist's dredge at a station in Kiel Bight $\left(54^{\circ} 37^{\prime} 50^{\prime \prime} \mathrm{N}, 10^{\circ} 20^{\prime} 10^{\prime \prime} \mathrm{E}\right)$ at a depth of $21 \mathrm{~m}$, a location with low oxygen content in the bottom water and hydrogen sulfide in the muddy sediment, particularly during late summer and autumn

Astarte borealis Schumacher and Arctica (Cyprina) islandica L., 100 to $250 \mathrm{mg}$ dry wt, were collected with a rectangular dredge at various stations of 16 to $22 \mathrm{~m}$ depth in Kiel Bight. The hydrographic data collected during these investigations were published by Oeschger \& Theede (1988). Animals were collected in September and October 1985, and in April 1986, and transported live to the laboratory. In order to provide shelter and to imitate the original habitat, sediment from the collection site was introduced into aquaria containing Halicryptus spinulosus at ambient temperature and salinity $\left(10^{\circ} \mathrm{C}, 18\right.$ to $\left.22 \% \mathrm{~S}\right)$. The bivalves were kept segregated without sediment in 201 plastic containers with aerated seawater $\left(10^{\circ} \mathrm{C}, 18 \% \mathrm{~S}\right)$. All animals were kept unfed and used for experiments usually within $6 \mathrm{~d}$ after dredging.

Environmental anoxia. Groups of 2 to 6 individuals were placed in flasks (100 to $2000 \mathrm{ml}$ volume) containing seawater free of oxygen (and sediment in the case of Halicryptus spinulosus), as described above. The seawater was flushed with pure nitrogen through an airstone for $30 \mathrm{~min}$ before and $15 \mathrm{~min}$ after transfer of the animals. The bottles were then sealed airtight for the entire duration of the incubation period, ranging from 1 to $60 \mathrm{~d}$. The absence of oxygen in the flasks was confirmed after 40 and $60 \mathrm{~d}$ of incubation with a Revsbech oxygen probe (Revsbech et al. 1980). The animals were tested for life signs immediately before homogenization for biochemical analysis. Valve closure reflex served as an index in the molluscs, and the contraction of the body wall after mechanical stimulation in Halicryptus spinulosus. In each group, some specimens were placed in well-aerated seawater to observe their recovery.

For all species dry weight was determined by drying a part of the whole frozen homogenized body tissue (excluding the shell in the bivalves). The factor (fresh wt/dry wt) for Halicryptus spinulosus was $8.40(\mathrm{n}=20)$, for Astarte borealis $7.79(\mathrm{n}=55)$ and for Arctica islandica $14.54(\mathrm{n}=50)$. The higher factor for $A$. islandica was caused by a comparatively high water content of the mantle cavity. Due to the need for immediate homogenization of the specimens, the water in the mantle cavity was also included in the metabolite analysis. Without this water the fresh wt/dry wt factor was $6.96(\mathrm{n}=5)$ in A. islandica.

Determination of glycogen. After incubation the animals were dissected and freeze-clamped immediately (Wollenberger et al. 1960). The frozen tissues were ground to a fine powder in a mortar pre-cooled with liquid nitrogen. Part of the powder was mixed with a 10 -fold (wt/vol) volume of boiling $0.02 \mathrm{~N} \mathrm{HCl}$, boiled for $10 \mathrm{~min}$ in a water bath, and re-homogenized with an ultrasonic rod for $30 \mathrm{~s}$. The suspension was kept at $4{ }^{\circ} \mathrm{C}$ overnight to dissolve the glycogen completely. Glycogen was determined in the supernatant according to Keppler \& Decker (1974) the supernatant 
was hydrolyzed with amyloglucosidase (E.C. 3.2.1.3.) under continuous mixing for $2 \mathrm{~h}$ at $40^{\circ} \mathrm{C}$. The resulting glucose was measured photometrically after centrifugation (ca $6200 \times g$ ) by the enzymatic hexokinase method.

Determination of metabolites. The metabolites were extracted with $0.6 \mathrm{~N}$ perchloric acid after preparation of the ground tissue powder according to Beis \& Newsholme (1975)

Standard enzymatic methods were employed for measuring L- and D-lactate (Gawehn \& Bergmeyer 1974) and succinate (Beutler 1985). Strombine and alanopine were determined after Siegmund \& Grieshaber (1983). Amino acids were quantified either by high performance liquid chromatography (Lindroth \& Mopper 1979, Dawson \& Liebezeit 1983), or with an amino acid analyzer (LC 6011, Biotronik). Acetate and propionate were estimated after ether extraction with a method modified after Guerrant et al. (1982).

Extraction and determination of pyruvate oxidoreductases. Directly after sampling at sea, animals were deep-frozen $\left(-35^{\circ} \mathrm{C}\right)$ and kept at this temperature for $5 \mathrm{~d}$ until analysis. Tissues were homogenized with an Ultra-Turrax homogenizer for $3 \times 15 \mathrm{~s}$ at maximum speed in a 10 -fold volume (wt/vol) of ice-cold $50 \mathrm{mM}$ imidazole buffer containing $1 \mathrm{mM}$ EDTA and $0.5 \mathrm{mM}$ mercaptoethanol, $\mathrm{pH} 7.5$, and centrifuged at $30000 \times \mathrm{g}$ for $20 \mathrm{~min}$. The supernatant was cleaned of low molecular weight compounds by passing it through a Sephadex G-25 column. The enzymes were assayed as described by Meinhardus-Hager \& Gäde (1986): lactate dehydrogenase $\left(\mathrm{NAD}^{+}\right.$-oxidoreductase, E.C. 1.1.1.27); octopine dehydrogenase [D-N-(1-carboxyethyl)-L-arginine: $\quad \mathrm{NAD}^{+}$-oxidoreductase, E.C. 1.5.1.11]; alanopine dehydrogenase [meso-N-(1-carboxyethyl)-alanine: $\mathrm{NAD}^{+}$-oxidoreductase, E.C. 1.5 .1 ? ]; strombine dehydrogenase [N-(carboxymethyl)(D)-alanine: $\mathrm{NAD}^{+}$-oxidoreductase, E.C. 1.5.1.?]. Tauropine dehydrogenase (E.C. 1.5.1.?) was assayed by a method modified after Sato \& Gäde (1986) and Gäde (1988)

Direct calorimetry. Calorimetric measurements on Astarte borealis and Arctica islandica were performed in a Pamatmat heat-flow double-twin calorimeter (Pamatmat 1978 ) at $10^{\circ} \mathrm{C}$. Specimens were sealed in a polyethylene bag containing a small amount of aerated, $0.2 \mu \mathrm{m}$ membrane-filtered seawater $\left(10^{\circ} \mathrm{C}, 18 \%\right.$ S), put into one of the pre-cooled twin chambers and transferred directly into the calorimeter.

The second chamber contained either membranefiltered seawater or air, and was used as a reference to monitor the baseline for any drift or fluctuation. The calibration constants of the 2 different measuring sites of the instrument for calculation of heat production were $1.52 \times 10^{-5} \mathrm{~W} \mu \mathrm{V}^{-1}$ and $2.38 \times 10^{-5} \mathrm{~W} \mu \mathrm{V}^{-1}$.

\section{RESULTS}

\section{Behavioural and environmental observations}

When Halicryptus spinulosus was kept in aquaria without sediment the worms were constantly in motion, presumably searching for sediment and trying to burrow. This activity appeared excessive from an experimental point of view and sediment was introduced into the aquaria to imitate their natural habitat. During the anoxia experiments, the worms at first remained active and continued to burrow most of the time, as observed through the glass walls of the incubation flasks, which permitted a view into some of the burrows. After $40 \mathrm{~d}$ of anoxia, the worms lay motionless on or in the sediment, but recovered after a few hours in aerated seawater. During anoxic incubation the colour of the body wall and of the coelomic fluid changed to black as hydrogen sulfide developed in the incubation flasks. The black colour has also been observed in freshly captured specimens (Oeschger \& Theede 1988).

Astarte borealis and Arctica islandica performed protruding movements with the foot during anoxic incubation, as described for Astarte montagui and Astarte elliptica by Dries \& Theede (1974). After a disturbance, they closed their valves only very slowly. At the end of the experiments, specimens transferred to aerated seawater usually burrowed into the sediment within $2 \mathrm{~h}$.

\section{Glycogen depletion}

Astarte borealis exhibited both the highest glycogen reserves and the longest survival time of all 3 species studied, followed by Arctica islandica. Halicryptus spinulosus had the lowest glycogen reserves. Glycogen utilization was high during the first $5 \mathrm{~d}$ of anoxic incubation, becoming slower with time (Fig. 1).

\section{Amino acids}

Small quantities of free amino acids were found in worms kept aerobically and in both bivalve species. Aspartic acid, known to be involved in anaerobic metabolism, disappeared in Halicryptus spinulosus after a few days of anaerobic incubation. At the same time, alanine levels decreased insignificantly, but increased again towards the end of the experimental period. No significant changes in the levels of other amino acids, including glutamic acid, were detected in $H$. spinulosus during anaerobic incubation (Fig. 2). 


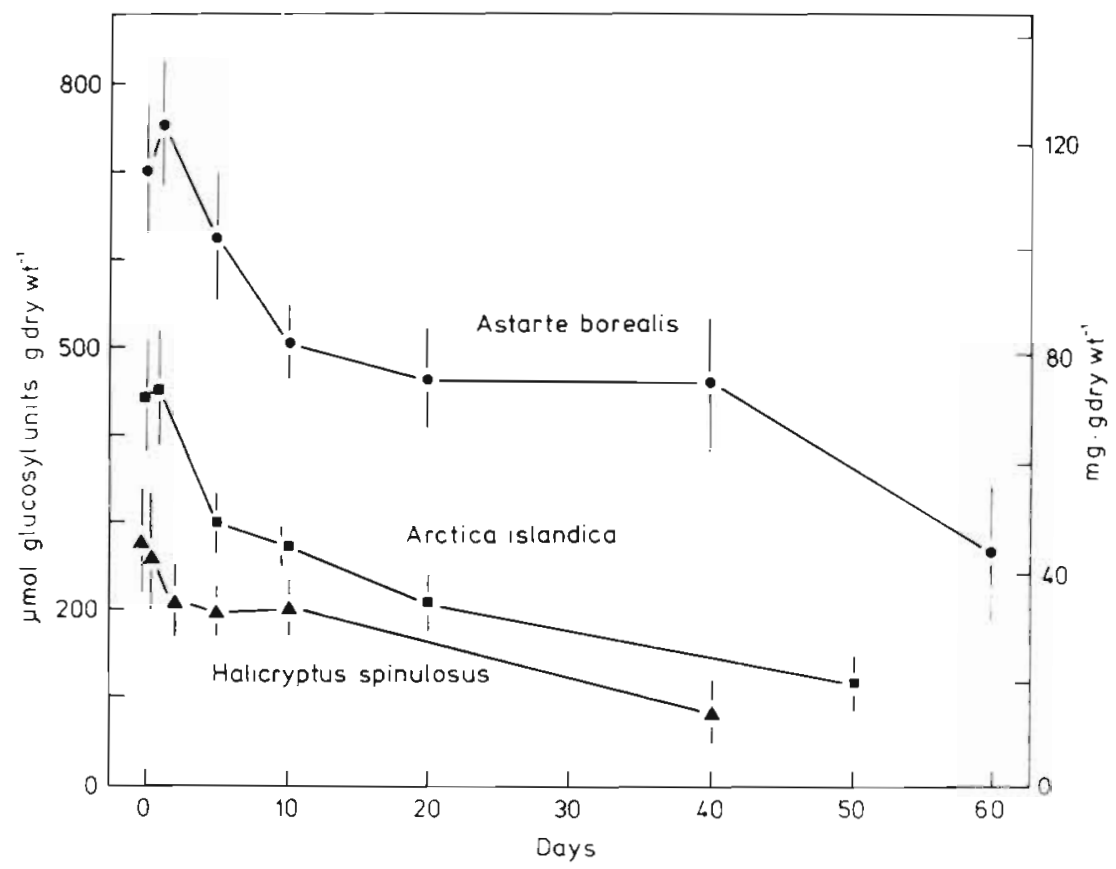

Fig. 1. Halicryptus spinulosus, Arctica is. landica and Astarte borealis. Decrease of glycogen stores during different periods of long-term anaerobiosis at $10^{\circ} \mathrm{C}$. (Mean values $\pm \mathrm{SD}, \mathrm{N}=4$ to 6 )

\section{Enzyme activities of pyruvate oxidoreductases and concentrations of glycolytic end-products}

Halicryptus spinulosus had a low activity of lactate dehydrogenase, and none of the known opine dehydrogenases (Table 1). Astarte borealis had low activities of alanopine and strombine dehydrogenase, and produced

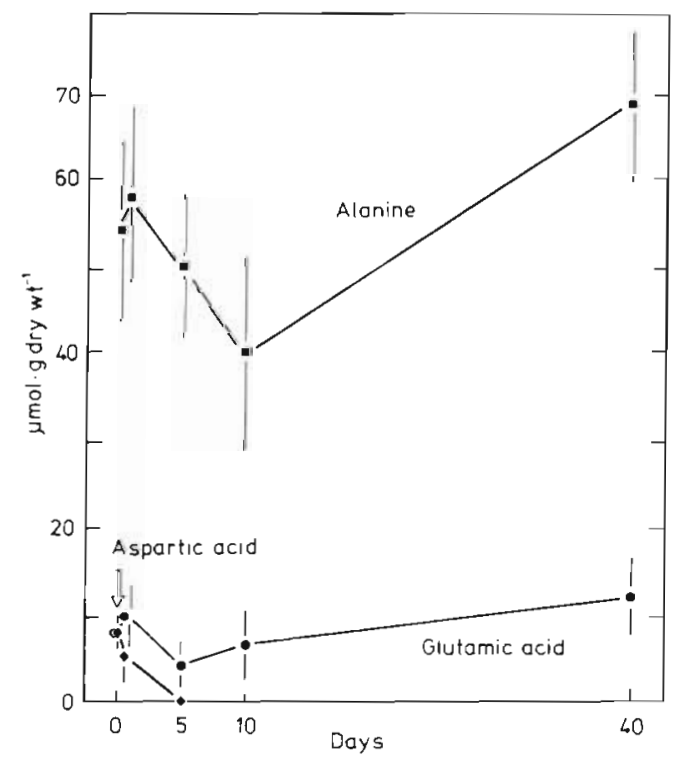

Fig. 2. Halicryptus spinulosus. Changes in amino acid concentrations during $40 \mathrm{~d}$ of anaerobrosis at $10^{\circ} \mathrm{C}$ (Mean values \pm $\mathrm{SD}, \mathrm{N}=4$ ) less than $2 \mu \mathrm{mol}$ ( $g$ dry wt) ${ }^{-1}$ of the glycolytic endproducts alanopine and strombine during anaerobic incubation at $5^{\circ} \mathrm{C}$. Octopine and tauropine dehydrogenase were completely absent in both species. Corresponding to the low LDH activities, L-lactate did not participate significantly in the anaerobic metabolism of $H$. spinulosus and $A$. borealis. Its isomer, D-lactate, was not detected either. In Arctica islandica, Livingstone et al. (1983) found significant activities of alanopine, strombine and octopine dehydrogenase.

\section{Changes in succinate concentrations}

All 3 species showed considerable increases in succinate levels during the first $5 \mathrm{~d}$ of anaerobiosis. Subsequently, succinate increased slowly in Halicryptus spinulosus and Astarte borealis, but continued to increase strongly in Arctica islandica. A. borealis had the lowest succinate levels, ca $85 \mu \mathrm{mol}$ ( $\mathrm{g}$ dry $w \mathrm{t})^{-1}$ at the end of the $60 \mathrm{~d}$ experiment, whereas $A$. islandica had the highest, ca $200 \mu \mathrm{mol}\left(\mathrm{g}\right.$ dry wt) ${ }^{-1}$ after $50 \mathrm{~d}$ (Fig. 3).

There was a conspicuously high concentration of succinate of about $22 \mu \mathrm{mol}(\mathrm{g} \text { dry } w \mathrm{t})^{-1}$ in Halicryptus spinulosus, even betore the beginning of the experiments. The succinate level remained high as long as the worms were buried in sediment. Placing the worms in aerated seawater without sediment led to diminution of succinate levels to $0.25 \pm 0.07$ umol (g dry wt) $(n=5)$ 
Table 1. Halicryptus spinulosus, Astarte borealis and Arctica islandica. Specific activities of pyruvate oxidoreductases in various tissues of samples from April 1986. Results are shown in units ( $\mathrm{g}$ fresh wt) ${ }^{-1}$

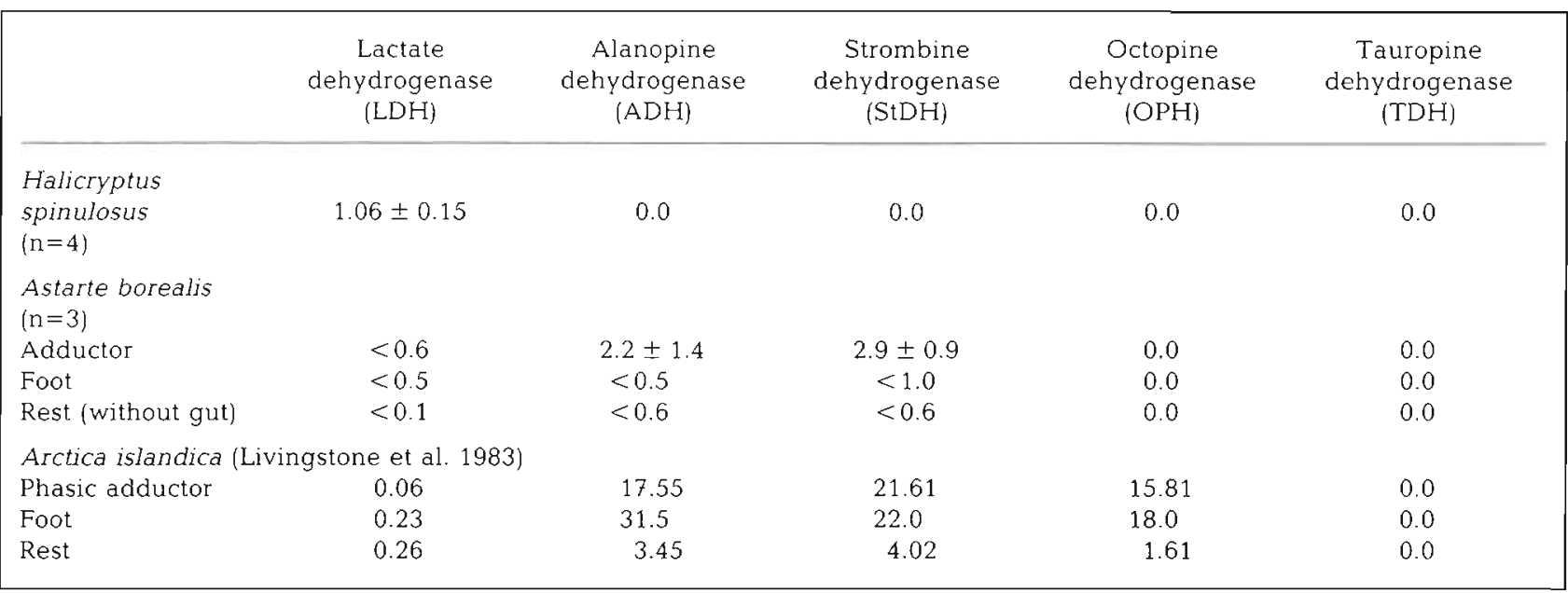

\section{Volatile fatty acids}

The tissues of Halicryptus spinulosus had acetate and propionate concentrations of about $10 \mu \mathrm{mol}$ (g dry $w t)^{-1}$ at the end of incubation under anoxia (Table 2). As the worms were incubated in their original sediment the amount of volatile fatty acids excreted by the worms into the seawater could not be assessed reliably. These are omitted in Table 2.

Astarte borealis produced high amounts of acetate and propionate. Remarkably, propionate under anoxia was only detectable after $2 \mathrm{~d}$ of anoxic incubation.
Although concentrations of fatty acids in the tissues were comparably low, considerable amounts (more than $300 \mu \mathrm{mol}$ ) were found in the incubation water. The reason for the low value for propionate in the incubation flask at the end of the experiment is unknown, but might have resulted from bacterial interactions.

Arctica islandica had the highest levels of both volatile acids. High concentrations were retained in the tissues. Propionate was produced in great amounts at the very beginning of anaerobiosis, and reached values of several hundred $\mu \mathrm{mol}$ ( $g$ dry $w t)^{-1}$ at the end of the experiments, whereas acetate increased strongly dur-

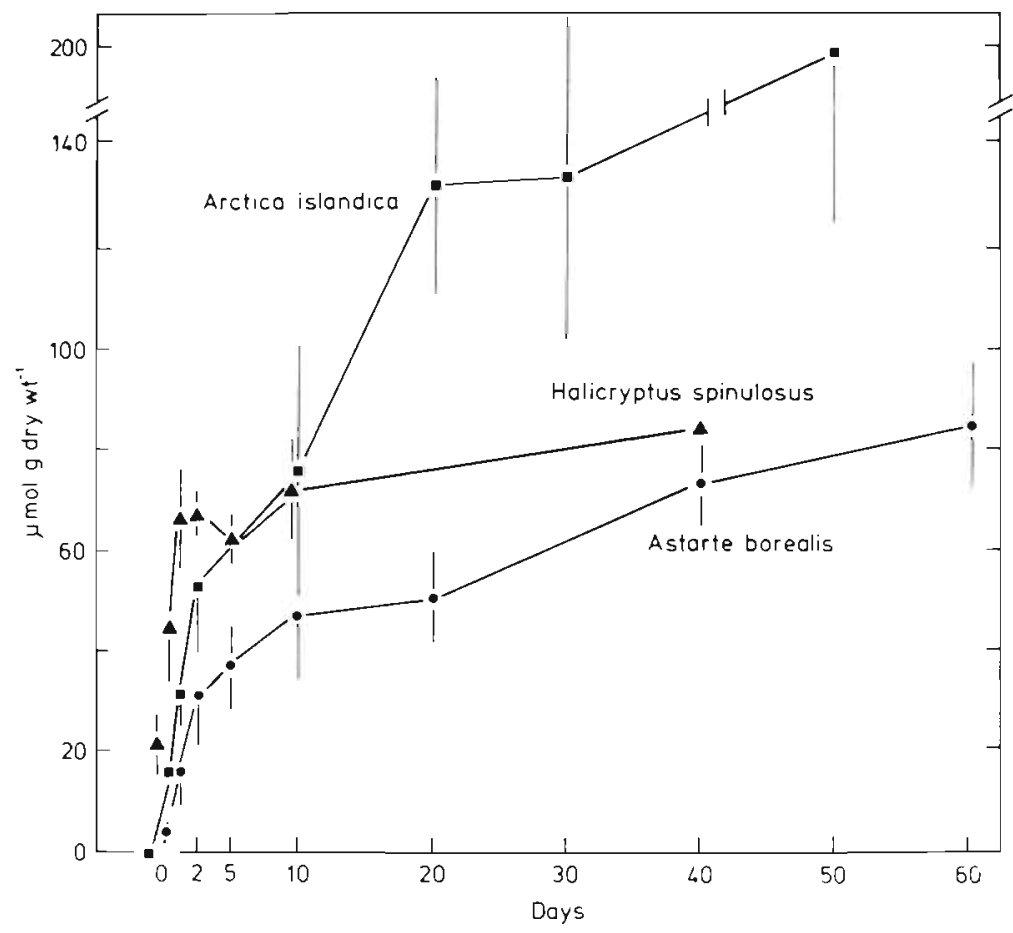

Fig. 3. Halicryptus spinulosus. Arctica islandica and Astarte borealis. Succinate accumulation during long-term anaerobiosis. (Mean values \pm $\mathrm{SD}, \mathrm{N}=4$ to 6 ) 
Table 2. Halicryptus spinulosus, Astarte borealis and Arctica islandica. Fatty acid concentration in tissues and incubation water after varying periods of anoxia in September and October 1985 . Temperature: $10^{\circ} \mathrm{C}$, salinity: $22 \%$ for $H$. spinulosus and $18 \%$ for bivalves. Values in $\mu \mathrm{mol}\left(\mathrm{g}\right.$ dry $\mathrm{wt}^{-1}$, mean values $\pm \mathrm{SD}, \mathrm{n}=4$ to 6 . Concentrations in incubation water converted to amounts produced per g animal dry wt

\begin{tabular}{|c|c|c|c|c|}
\hline \multirow[t]{2}{*}{$\begin{array}{l}\text { Time under } \\
\text { anoxia (d) }\end{array}$} & \multicolumn{2}{|c|}{$\begin{array}{l}\text { Concentration in tissues } \\
\left(\mu \mathrm{mol}[\mathrm{g} d r y \mathrm{wt}]^{-1}\right)\end{array}$} & \multicolumn{2}{|c|}{$\begin{array}{l}\text { Concentration in } \\
\text { incubation water } \\
\left(\mu \mathrm{mol}[\mathrm{g} \text { dry } w t]^{-1}\right)\end{array}$} \\
\hline & Acetate & Propionate & Acetate & Propionate \\
\hline \multicolumn{5}{|c|}{ Halicryptus spinulosus } \\
\hline Start & $2.1 \pm 1.3$ & $2.0 \pm 0.6$ & $a$ & a \\
\hline 2 & $8.2 \pm 2.4$ & $7.4 \pm 2.1$ & & \\
\hline 5 & $12.8 \pm 9.7$ & $10.7 \pm 2.8$ & & \\
\hline 10 & $6.8 \pm 1.3$ & $7.3 \pm 2.8$ & & \\
\hline 40 & $9.9 \pm 6.4$ & $10.9 \pm 7.9$ & & \\
\hline \multicolumn{5}{|c|}{ Astarte borealis } \\
\hline Start & $4.8 \pm 2.9$ & 0.0 & 0.0 & 0.0 \\
\hline 2 & $15.0 \pm 6.1$ & $0.5 \pm 0.7$ & 11.8 & 0.0 \\
\hline 10 & $8.4 \pm 4.7$ & $5.3 \pm 2.2$ & 26.7 & 31.9 \\
\hline 20 & $9.2 \pm 1.9$ & $9.4 \pm 3.8$ & 157.1 & 284.5 \\
\hline 40 & $9.4 \pm 3.4$ & $5.5 \pm 3.2$ & 326.0 & 264.5 \\
\hline 60 & $9.6 \pm 1.5$ & $3.8 \pm 0.7$ & 332.5 & 16.2 \\
\hline \multicolumn{5}{|c|}{ Arctica islandica } \\
\hline Start & $4.1 \pm 0.4$ & $4.4 \pm 7.0$ & 0.0 & 0.0 \\
\hline 1 & $23.5 \pm 7.2$ & $238.7 \pm 50.4$ & 0.0 & 0.0 \\
\hline 5 & $66.6 \pm 36.7$ & $232.5 \pm 146.4$ & 87.7 & 12.3 \\
\hline 20 & $36.3 \pm 12.8$ & $216.1 \pm 40.7$ & 122.4 & 35.1 \\
\hline 50 & $20.9 \pm 12.5$ & $366.3 \pm 143.2$ & 428.6 & 15.4 \\
\hline
\end{tabular}

ing the first days of incubation, decreasing again towards the end of the experiments (Table 2).

\section{Heat production and reduced metabolism in bivalves}

Heat production could only be measured after thermal equilibration inside the calorimeter, 5 to $6 \mathrm{~h}$ after insertion of specimens into the chambers.

Heat production in Astarte borealis declined by $40 \%$ from $21.1 \pm 1.1$ at the beginning to $12.5 \pm 1.1 \mathrm{~J}$ (g dry $w t)^{-1} h^{-1}$ after $24 \mathrm{~h}$ in the calorimeter $(\mathrm{n}=5$; individuals of 133.5 to $230 \mathrm{mg}$ dry $\mathrm{wt}$ ). Heat production in Arctica islandica declined by $35 \%$ from $17.9 \pm 6.1$ to $11.7 \pm 2.6 \mathrm{~J}\left(\mathrm{~g}\right.$ dry $\mathrm{wt}^{-1} \mathrm{~h}^{-1}$ after $1 \mathrm{~d}$ in the calorimeter ( $n=4$; individuals of 163.8 to $181.5 \mathrm{mg}$ dry $w \mathrm{t}$ ).

At the end of incubation, metabolic rates of both bivalve species were less than $1 \%$ of the aerobic values (see Table 3 in 'Discussion').

\section{DISCUSSION}

The response of the sublittoral species Halicryptus spinulosus, Astarte borealis and Arctica islandica to prolonged anoxia showed characteristic differences to intertidal species regularly subjected to short periods of oxygen depletion.

\section{Species-specific energy metabolism during long-term anaerobiosis}

\section{Halicryptus spinulosus}

Glycogen is the essential substrate for anaerobic long-term metabolism. The relatively small glycogen stores in Halicryptus spinulosus depend on seasonal influences (Oeschger \& Theede 1988). Although glycogen storage levels in $H$. spinulosus are similar to those of the polychaete Arenicola marina (Schöttler et al. 1984), it survives oxygen deficiency far longer.

During the initial phase of short-term anaerobiosis, the mussel Mytilus edulis metabolizes aspartic acid to alanine and succinate, with concomitant accumulation of alanine (de Zwaan 1977). In the case of Halicryptus spinulosus, aspartic acid decreased with only a slight increase in alanine. The fluctuations in alanine concentrations between 10 and $40 \mathrm{~d}$ of anoxic exposure may be due to natural variation between individuals. The fluctuations were not significant, and this particular anaerobic metabolic pathway does not play an impor- 
tant role in long-term anaerobiosis. Moreover, $H$. spinulosus has only a low lactate dehydrogenase activity and no other opine dehydrogenase activity, which confirms findings of Livingstone et al. (1983) for Priapulus caudatus. Therefore, glycolytic end-products seem to be of little importance in these priapulid species

The formation of succinate by Halicryptus spinulosus during long-term oxygen deficiency is very important. Worms collected in late summer and autumn show large amounts of succinate in their tissues, correlating with low glycogen concentrations. Laboratory experiments showed that succinate is oxidized only after several days in aerated seawater. This indicates that $H$. spinulosus frequently lives anaerobically in situ (Oeschger \& Theede 1988). Concomitant to the elevated succinate concentrations during long-term anderobiosis, this species also produces high quantities of volatile fatty acids, acetate and propionate.

\section{Astarte borealis and Arctica islandica}

Astarte borealis showed the highest glycogen content of the species investigated here, as well as displaying the highest $\mathrm{LT}_{50}$-values under anaerobic conditions known for marine invertebrates (Theede et al. 1969). The low activities of lactate, alanopine and strombine dehydrogenases indicate a subordinate role of anaerobic glycolysis during long-term anaerobiosis. Alanopine and strombine slightly increased only during the first hours of anoxia. Of the species studied, $A$. borealis showed the lowest increase in succinate. Evidently this species produces acetate from the onset of anaerobiosis, while propionate production is delayed for the first $2 \mathrm{~d}$ of adaptation to anoxia. Activation or induction of enzymes involved in metabolization of succinate to propionate may be responsible for this delay. The overall energy production (calculated as ATP formation per hour) from the metabolites measured dropped to about 1.4 ATP molecules $h^{-1}$ at the end of the experiments, but there was an increase in ATP production between 10 and $40 \mathrm{~d}$ of incubation which cannot readily be explained. Possible explanations are increased activity (e.g. search movements with the foot) or undesired bacterial influences in the incubation flasks.

Arctica islandica has a slightly shorter survival time under oxygen deficiency than Astarte borealis (Theede et al, 1969), which correlates with its somewhat lower glycogen levels. There is contradictory information on the activities of opine dehydrogenases in $A$. islandica. Dando et al. (1981) found only strombine and octopine dehydrogenases, whereas Livingstone et al. (1983) additionally found alanopine dehydrogenase in various tissues (Table 1). A high activity of octopine dehydrogenase in the foot was determined in both cases. Formation of octopine is important during functional anaerobiosis (Gäde \& Grieshaber 1986), e.g. for escape movements, as demonstrated in Cardium tuberculatum (Meinhardus-Hager \& Gäde 1986). A. islandica sometimes burrows into the anoxic sediment without any apparent reason (Taylor 1976, own obs.). Also, when sediment conditions require this, the bivalves may be able to change their position. The octopine pathway may provide additional energy to the foot during this burrowing activity, as has been shown for Ensis directus (Schiedek \& Zebe 1987).

Succinate production was very high in Arctica islandica, emphasizing the importance of this pathway during long-term anaerobiosis. In contrast to both other species studied, A. islandica produced large amounts of acetate and propionate from the very onset of environmental anoxia. This immediate anaerobic energy production seems biologically important, when the bivalves undergo self-induced anaerobiosis by burrowing deeply into the sediment. The high production of propionate implies a higher rate of ATP formation than is the case in Astarte borealis. During the first day of anaerobiosis the ATP production is much higher than ascertained for any marine invertebrate so far, and this may be related to frequent self-induction of anaerobiosis. However, this explanation would require further study. Another feature of anaerobic metabolism in $A$. islandica is that glycogen degradation and concomitant formation of metabolites do not balance. The metabolite concentrations appear excessive, and additional energy-supplying pathways not yet elucidated (e.g. from proteins) may possibly be used during long-term anaerobiosis

The storage, rather than excretion, of energy-rich fatty acids should be an adaptation to frequent anaerobiosis, limiting the loss of valuable energy resources which can be re-oxidized under aerobic conditions. The problems associated with acidosis in the tissues can be overcome by well-developed buffering capacities, and some bivalve species are known to prevent acidosis by mobilizing carbonate from their shells (Crenshaw \& Neff 1969, Crenshaw 1972, Greenfield \& Crenshaw 1980). In Arctica islandica, Pamatmat (1980) observed milky-looking substances, possibly $\mathrm{CaCO}_{3}$, oozing out of the valves after prolonged anoxia, and Weigelt (pers. comm.) observed thinner valves in sampling areas in Kiel Bight which are often subjected to oxygen depletion. Astarte borealis, on the other hand, retains only small amounts of volatile fatty acids within its tissues and its valves are much thicker. The 2 species seem to have a different reliance on the carbonate buffer system due to different concentrations of fatty acids during anaerobiosis. Other intracellular 
buffering systems are also possible, however. Dominant intracellular buffers in marine teleosts, for instance, are of an imidazole type (Somero 1981, Castellini \& Somero 1981). The buffering systems in marine invertebrates often confronted with prolonged anoxia remain to be investigated in detail.

\section{Reduction of metabolism}

A strong reduction of metabolism seems to be a prerequisite for prolonged survival under anoxia. It varies greatly between species. Some species, such as Mulina lateralis, do not reduce their metabolism at all under anoxia (Shumway et al. 1983). Some crustaceans reduce their metabolism only slightly during anoxia (Pamatmat 1980), and this is also true for some Mediterranean bivalve species (Kluytmans et al. 1983). Some intertidal marine invertebrates reduce their metabolic rate to $5 \%$ of aerobic rates after $2 \mathrm{~d}$ of anoxic incubation, e.g. Mytilus edulis and Modiolus demissus (Pamatmat 1980).

Because environmental anoxia should normally come about gradually rather than abruptly, calorimetric measurements simulate natural conditions. The small amount of oxygen initially available in the water allows the animals to gradually reduce their metabolism. Calorimetric measurements on Arctica islandica and Astarte borealis demonstrated a reduction of the heat production rate by as much as $40 \%$ during the first day of experiments (Table 3 ). Table 3 shows the metabolic energy production of the bivalves after varying periods of anaerobiosis.

Values are compiled as follows: The aerobic energy production was extrapolated to obtain a value for the beginning of the experiments. The anaerobic heat production after $1 \mathrm{~d}$ was obtained from the calorimetric measurement. The third column of Table 3 shows the subsequent heat production calculated from the caloric equivalent in the dissipative ATP turnover resulting from the anaerobic breakdown of glycogen to succinate, acetate and propionate. The bivalves' energy production in the resulting anoxic periods was calculated on the basis of the metabolites analyzed, postulating that glycogen was the only energy-supplying substrate during the later phase of long-term anaerobiosis. Energy production was calculated after values given by de Zwaan \& Wijsman (1976) and Pörtner et al. (1984) for the anaerobic ATP yield per $\mu \mathrm{mol}$ of metabolite formed. Each umol of acetate and succinate produced in anaerobic metabolism corresponds to $2.5 \mu \mathrm{mol}$ ATP, and 1 umol of propionate corresponds to $3.5 \mu \mathrm{mol}$ ATP. The formation of these metabolites from glycogen in dissipative metabolism (i.e. conversion of biochemically bound energy to heat loss during metabolic processes) corresponds to a heat equivalent of $0.047 \mathrm{~J}$ per metabolically produced umol acetate, $0.057 \mathrm{~J}$ for succinate and $0.043 \mathrm{~J}$ for propionate (Gnaiger 1980). To obtain the values in the third column of Table 3, the ATP yield from anaerobic degradation of glycogen to the metabolites analyzed was multiplied by the corresponding enthalpy of the reactions (for more details see Gnaiger 1980).

Table 3. Arctica islandica and Astarte borealis. Heat production after varying periods under anoxia, from measurements of direct heat production, aerobic values by extrapolation, and values for 20 to $60 \mathrm{~d}$ of anoxia calculated from anaerobic metabolites. Specimens collected in September 1985. Values in $J(g \text { dry } w t)^{-1} d^{-1}$ are rounded. For details see text

\begin{tabular}{|c|c|c|c|c|}
\hline $\begin{array}{l}\text { Days under } \\
\text { anoxia }\end{array}$ & $\begin{array}{c}\text { Measured heat } \\
\text { production in } \\
\text { the calorimeter } \\
\left(\mathrm{J}[\mathrm{g} d r y \mathrm{wt}]^{-1}\right. \\
\left.\mathrm{d}^{-1}\right)\end{array}$ & $\begin{array}{c}\text { Heat production } \\
\text { calculated from } \\
\text { analyzed } \\
\text { metabolites } \\
\left(J[g d r y \text { wt }]^{-1}\right. \\
\left.d^{-1}\right)\end{array}$ & $\begin{array}{c}\text { Heat production } \\
\text { as proportion of } \\
\text { aerobic value } \\
(\%)\end{array}$ & $\begin{array}{c}\text { Participation of } \\
\text { analyzed } \\
\text { metabolites in } \\
\text { anaerobic ener- } \\
\text { gy metabolism } \\
(\%)\end{array}$ \\
\hline \multicolumn{5}{|c|}{ Arctica islandica } \\
\hline Aerobic & 430 & - & 100 & - \\
\hline 1 & 280 & 50 & 65 & 12 \\
\hline 20 & - & 4 & $<1$ & $100^{\mathrm{d}}$ \\
\hline 50 & - & 3 & $<0.7$ & $100^{d}$ \\
\hline \multicolumn{5}{|c|}{ Astarte borealis } \\
\hline Aerobic & 500 & - & 100 & - \\
\hline 1 & 300 & 5 & 60 & $<2^{\prime \prime}$ \\
\hline 20 & - & 3 & $<0.7$ & $100^{d}$ \\
\hline 60 & - & 1.5 & $<\quad 0.5$ & $100^{-1}$ \\
\hline
\end{tabular}


The bivalves continued to reduce their metabolism during anoxia down to far below $1 \%$ of the aerobic rate. These are the lowest rates of anaerobic energy production calculated for marine invertebrates so far. The results, however, are based on the assumption that no substrates other than glycogen are significantly involved in long-term anaerobic energy metabolism. The calorimetrically measured value of a specimen of Arctica islandica after $10 \mathrm{~d}$ of anoxia (re-calculated after Pamatmat 1980) confirms these calculations on the base of the acetate, propionate, and succinate levels measured in this study. These metabolites are only of minor significance during the initial transition to anaerobic metabolism, accounting at first for only $2 \%$ (Astarte borealis) and $12 \%$ (A. islandica) of the total heat production. Phosphagens might be an important supplementary source to meet metabolic energy demands, as has been shown for several intertidal animals (e.g. Siegmund et al. 1985, Schiedek \& Zebe 1987, Schöttler \& Grieshaber 1988).

Functional anaerobiosis is generally related to the well-known 'fight-and-flight' reactions, whereas environmentally induced anaerobiosis is caused by the absence of oxygen or by other adverse environmental conditions. Arctica islandica, however, spontaneously induces anaerobic conditions by burrowing aperiodically into the sediment for extended periods, and no triggering factor is yet known for this behaviour (Taylor 1976). Certain adverse environmental stimuli (e.g. the presence of noxious substances, unusual physical disturbances or prolonged absence of food), or even unknown endogenous conditions, may be triggering factors. A. islandica is an important element in the diet of benthic and pelagic fish (Weigelt \& Rumohr 1986), and burrowing deep into the sediment should provide excellent protection from predators. The glycogen stores will last much longer under anaerobic conditions than would be the case during aerobic starvation, as can be shown by calorimetric measurements. Thus, 'energy-induced anaerobiosis', i.e. passive avoidance of adverse environmental conditions through active burrowing into anoxic sediment, may have developed as an evolutionary advantage.

Halicryptus spinulosus also shows reactions which go beyond the conventional definition of environmentally induced anaerobiosis. In the sampling area, where muddy sediment contains high amounts of organic matter and low to zero oxygen levels, specimens burrowing as deep as $30 \mathrm{~cm}$ are regularly found. Laboratory observations confirm that the worms actively move into and within the anaerobic sediment layers. This may explain why the worms have high concentrations of succinate in their tissues when kept in aerated aquaria with sediment. It remains to be ascertained whether they feed under anoxia. Famme \&
Knudsen (1984) demonstrated a positive energy balance, growth and reproduction of Tubifex sp. under oxygen deficiency, and this species even exhibits negative aerotaxis. All these findings indicate a high degree of facultativeness in the various species ability to cope with oxygen deficiency.

\section{CONCLUSIONS}

The transition to anaerobic metabolism in the sublittoral species Halicryptus spinulosus, Astarte borealis and Arctica islandica seems comparable to that in intertidal animals. The involvement of phosphagens, as detected by ${ }^{31} \mathrm{P}$-NMR spectroscopy in Halicryptus spinulosus (Kamp pers. comm.), might correspond with observations in intertidal animals during the onset of anaerobiosis. This presumption is supported by the finding that at the beginning of anaerobiosis the bivalve species investigated covered only a small percentage of metabolic energy demand by those anaerobic pathways generating succinate, acetate and propionate. Remarkably, the 3 sublittoral species studied here relied very little on those pathways which are of special significance in short-term anaerobiosis in intertidal animals, such as amino acid metabolism and anaerobic glycolysis to lactate and various opines for ATP generation. For intertidal Arenicola marina, anaerobic glycolysis is of great importance (Siegmund et al. 1985), but the accumulation of high concentrations of such metabolites incurs the danger of acidosis and disturbance of osmotic equilibria. Reduced production of lactic acid and opines, and excretion of fatty acids, therefore appear to be adaptations of sublittoral animals to prolonged environmental anoxia. The retention of propionate by $A$. islandica is a possible adaptation to frequent self-induced anaerobiosis of limited duration.

Glycogen utilization and resulting succinate production are essential for energy metabolism during longterm anaerobiosis. The species studied here did not metabolize succinate quantitatively into propionate, so that succinate also constitutes an anaerobic end-product metabolite.

Large stores of glycogen in marine invertebrates (up to $40 \%$; de Zwaan \& Wijsman 1976) are generally considered essential for anaerobiosis under short-term conditions. The glycogen levels of only 5 to $12 \%$ (dry $w t)$ found in the 3 present species were much lower than those, for example, in Mytilus edulis. Obviously, high glycogen content is not a critical prerequisite for long-term survival in the absence of oxygen. The essential factor for long-term survival under anoxia is the reduction of metabolic rate. Intertidal invertebrates have been shown to be capable of a reduction down to 
$5 \%$ of the aerobic value, whereas both bivalves investigated in the present study were able to reduce their metabolism to less than $1 \%$ of the aerobic rate.

Acknowledgements. This paper represents part of the author's thesis at the Institut für Meereskunde at the University of Kiel in the fulfilment of the Dr rer. nat requirements. In thank Prof. $\mathrm{Dr} H$. Theede for his generous support, continuous advice and helpful discussions during the realization of this work. I am indebted to Prof. Dr M. Grieshaber and Dr B. Siegmund for their help with the measurement of alanopine and strombine, and Prof. Dr G. Gäde for support in determining the activities of opine dehydrogenases (all Institut für Stoffwechselphysiologie, Universität Düsseldorf). Priv. Doz. Dr G. Graf (Institut für Meereskunde, Kiel) and Dr M. M. Pamatmat (AlfredWegener-Institut, Bremerhaven) and anonymous referees gave valuable comments on former drafts of the manuscript. I thank Dipl.-Biol. M. Seaman (Institut für Meereskunde, Kiel) for corrections and comments on the English manuscript.

\section{LITERATURE CITED}

Arntz, W. E. (1980). Predation by demersal fish and its impact on the dynamics of macrobenthos. In: Tenore, K. R., Coull, B. C. (eds.) Marine benthic dynamics. University of South Carolina Press, Columbia, p. 121-149

Beis, I., Newsholme, E. A. (1975). The contents of adenine nucleotides, phosphagens and some glycolytic intermediates in resting muscles from vertebrates and invertebrates. Biochem. J. 152: 23-32

Beutler, H.-O. (1985). Succinate. In: Bergmeyer, J., Graßl, M. (eds.) Methods of enzymatic analysis. Vol. VII. Verlag Chemie, Weinheim, p. 25-33

Castellini, M. A., Somero, G. N. (1981). Buffering capacity of vertebrate muscle: correlations with potentials for anaerobic function. J. comp. Physiol. B 143: 191-198

Crenshaw, M. A. (1972). The inorganic composition of molluscan extrapallial fluid. Biol. Bull. mar biol. Lab., Woods Hole 143: 506-512

Crenshaw, M. A., Neff, J. M. (1969). Decalcification at the mantle-shell interface in molluscs. Am. Zool. 9: 881-885

Dando, P. R., Storey, K. B., Hochachka, P. W., Storey, J. M. (1981). Multiple dehydrogenases in marine molluscs: electrophoretic analysis of alanopine dehydrogenase, strombine dehydrogenase, octopine dehydrogenase and lactate dehydrogenase. Mar. Biol. Lett. 2: 24.9-257

Dawson, R., Liebezeit, G. (1983). Determination of amino acids and carbohydrates. In: Grasshoff, K., Ehrhardt, M., Kremling, K. (eds.) Methods of seawater analysis. Verlag Chemie, Weinheim, p. 319-346

Dries, R.-R., Theede, H. (1974). Sauerstoffmangelresistenz mariner Bodenevertebraten aus der Westlichen Ostsee. Mar. Biol. 25: 327-333

Ehrhardt, M., Wenck, A. (1984). Wind pattern and hydrogen sulfide in shallow waters of the Western Baltic Sea, a cause and effect relationship? Meeresforsch. 30: 101-110

Famme, P., Knudsen, J. (1984). Metazoan life under permanent anoxic conditions? In: First congress of comparative physiology and biochemistry, Section of International Union of Biological Sciences, Liege 1984. Vol. A: 110-111

Fields, J. H. A., Storey, K. B. (1987). Tissue-specific alanopine dehydrogenase from gill and strombine dehydrogenase from the foot muscle of the cherrystone clam Mercenaria mercenaria (Linn.). J. exp. mar Biol. Ecol. 105: 175-185
Gäde, G., Grieshaber, M. K. (1986). Pyruvate reductases catalyze the formation of lactate and opines in anaerobic invertebrates. Comp. Biochem. Physiol. 83 B: 255-272

Gawehn, K., Bergmeyer, H. U. (1974). D-(-)-Laktat. In: Bergmeyer, H. U. (ed.) Methoden der enzymatischen Analyse, Bd. II Verlag Chemie, Weinheim, p. 1538-1541

Gnaiger, E. (1980). Das kalorische Äquivalent des ATPUnsatzes in anaeroben und anoxischen Metabolismus. Thermochim. Acta 40: 195-223

Greenfield, E., Crenshaw, M. A. (1981). Variations in the rate of anaerobic succinate accumulation within the central and marginal regions of an euryoxic bivaive mantle. P. S. Z. N. I. Mar. Ecol. 2 (4): 353-362

Guerrant, G. O., Lambert, M. A., Moss, W (1982). Analysis of short-chain acids from anaerobic bacteria by high-performance liquid chromatography. J. clin. Microbiol. 16: 355-350

Keppler, D., Decker, K. (1974). Glykogen. In: Bergmeyer, H. U. (ed.) Methoden der enzymatischen Analyse, Bd. II. Verlag Chemie, Weinheim, p. 1089-1094

Kluytmans, J. H., de Bont, A. M. T., Kruitwagen, E. C. J., Ravestein, H. J. L., Veenhof, P. R. (1983). Anaerobic capacities and anaerobic energy production of some Mediterranean bivalves. Comp. Biochem. Physiol. 75B: $171-179$

Land, J. van der (1970). Systematics, zoogeography, and ecology of the Priapulida. Zool. Verh., Leiden 112: 1-122

Lindroth, P., Mopper, K. (1979). High performance liquid chromatographic determination of subpicomole amounts of amino acids by pre-column fluorescence derivatization with o-phthaldialdehyde. Analyt. Chem. 51: 1667-1674

Livingstone, D. R., de Zwaan, A., Leopold, M., Marteijn, E. (1983). Studies on the phylogenetic distribution of pyruvate oxidoreductases. Biochem. Syst. Ecol. 11: 415-425

Mejnhardus-Hager, G., Gäde, G. (1986). The pyruvate branch point in the anaerobic energy metabolism of the jumping cockle Cardium tuberculatum L.: D-lactate formation during environmental anaerobiosis versus octopine formation during exercise. J. exp. Biol. 45: 91-110

Oeschger, R. (1987). Vergleichende Untersuchungen zur biotopbedingten Langzeit-Anaerobiose und Schwefelwasserstoff-Resistenz bei einigen marinen Wirbellosen aus der Ostsee. Thesis, University of Kiel

Oeschger, R., Theede, H. (1986). Untersuchungen zur Langzeit-Anaerobiose bei Halicryptus spinulosus (Priapulida). Verh. dt. zool. Ges. 79: 401

Oeschger, R., Theede, H. (1988). Use of biochemical features of macrobenthic species as indicators of long-term oxygen deficiency. Kieler Meeresforsch., Sonderh. 6: 99-110

Pamatmat, M. M. (1978). Oxygen uptake and heat production in a metabolic conformer (Littorina irrotata) and a metabolic regulator (Uca pugnax). Mar Biol. 48: 317-325

Pamatmat, M. M. (1980). Facultative anaerobiosis of benthos. In: Tenore, K. R., Coull, B. C. (eds.) Marine benthic dynamics. University of South Carolina Press, Columbia, p. $65-90$

Pörtner, H.-O., Kreutzer, U., Siegmund, B., Heisler, N. Grieshaber, M. K. (1984). Metabolic adaptation of the intertidal worm Sipunculus nudus to functional and environmental hypoxia. Mar. Biol. 79: 237-247

Revsbech, N. P., Jorgensen, B. B., Blackburn, T H. (1980). Oxygen in the sea bottom measured with a microelectrode. Science 207: 1355

Sato, M., Gäde, G. (1986). Rhodic acid dehydrogenase: a novel amino acld-linked dehydrogenase from muscle tissue of Haliotis species. Naturwissenschaften 73: $207-208$ 
Schiedek, D., Zebe, E. (1987). Functional and environmental anaerobiosis in the razor-clam Ensis directus (Mollusca: Bivalvia). Mar. Biol. 94:31-37

Schöttler, U. (1979). On the anaerobic metabolism of three species of Nereis (Annelida). Mar. Ecol. Prog. Ser 1: $249-254$

Schöttler, U., Grieshaber, M. (1988). Adaptation of the polychaete worm Scoloplos armiger to hypoxic conditions. Mar. Biol. 99: 215-222

Schöttler, U., Wienhausen, G., Westermann, J. (1984) Anaerobic metabolism in the lugworm Arenicola marina L.: the transition period from aerobic to anaerobic metabolism. Comp. Biochem. Physiol. 79 B: 93-103

Shumway, S. E., Scott, T. M., Shick, J. M. (1983). The effects of anoxia and hydrogen sulphide on survival, activity and metabolic rate in the coat clam, Mulina lateralis (Say). J. exp. mar. Biol. Ecol. 71: 135-146

Siegmund, B., Grieshaber, M. K. (1983). Determination of meso-alanopine and D-strombine by HPLC in extracts from marine invertebrates. Hoppe-Seyler's Z physiol Chem. 364: 807-812

Siegmund, B., Grieshaber, M., Reitze, M., Zebe, E. (1985) Alanopine and strombine are end products of anaerobic glycolysis in the lugworm, Arenicola marina L. (Annelida, Polychaeta). Comp. Biochem. Physiol. 82 B: 337-345

Somero, G. N. (1981). pH-temperature interactions on proteins: principles of optimal $\mathrm{pH}$ and buffer system design. Mar. Biol. Lett. 2: 163-178

This article was submitted to the editor
Storey, K. B. (1988). Suspended animation: the molecular basis of metabolic depression. Can. J. Zool. 66: 124-132

Taylor, A. C. (1976). Burrowing behaviour and anaerobiosis in the bivalve Arctica islandica (L.). J. mar biol. Ass. U. K. 56 : 95-109

Theede, H. (1984). Physiological approaches to environmenta] problems of the Baltic. Limnologica (Berl.) 15: 443-458

Theede, H., Ponat, A., Hiroki, K., Schlieper, C. (1969). Studies on the resistance of marine bottom invertebrates to oxygen deficiency and hydrogen sulphide. Mar Biol. 2: 325-337

Weigelt, M., Rumohr, $H_{\text {. (1986). Effects of wide range oxygen }}$ depletion on benthic fauna and demersal fish in Kiel Bay 1981-1983. Meeresforsch. 31: 124-136

Wollenberger, A., Ristau, O., Schoffa, G. (1960). Eine einfache Technik der extrem schnellen Abkühlung größerer Gewebestücke. Pflügers Arch. 270; 399-412

Zebe, E. (1977). Anaerober Stoffwechsel bei wirbellosen Tieren. Rheinisch.-Westf. Akademie der Wissensch. Vorträge N 269: 51-73

Zebe, E., Grieshaber, M. K., Schöttler, U. (1980). Biotopbedingte und funktionsbedingte Anaerobiose. Der Energiestoffwechsel wirbelloser Tiere bei Sauerstoffmangel Biologie in unserer Zeit 10: 175-182

Zwaan, A. de, (1977). Anaerobic energy metabolism in bivalve molluscs. Oceanogr. mar. Biol. A. Rev. 15: 103-197

Zwaan, A. de, Wijsman, T C. (1976). Anaerobic metabolism in bivalvia (Mollusca). Characteristics of anaerobic metabolism. Comp. Biochem. Physiol. 54 B: 313-324

Manuscript first received: October 10, 1988

Revised version accepted: September 12, 1989 